\title{
LAS ESCLAVAS AMAZONAS (1805) DE MARÍA ROSA DE GÁLVEZ EN LA COMEDIA POPULAR DE ENTRESIGLOS
}

\author{
Helena EsTABLIER PÉREZ
}

Universidad de Alicante

\section{RESUMEN}

Las Esclavas Amazonas (1805) es la última comedia original escrita por María Rosa de Gálvez (1768-1806) y la única en la que la autora malagueña se ciñe a los esquemas del teatro popular de entresiglos, lo cual ha producido un cierto desinterés crítico por esta obra, frente a las tragedias y las comedias de la dramaturga más cercanas a los intereses neoclásicos. Partiendo del estudio de sus fuentes, este trabajo trata de mostrar que si bien en los aspectos formales la obra se acerca a los recursos propios del teatro mayoritario, la actualización que plantea del mito amazónico, al servicio de la reivindicación de género que subyace a la producción dramática de la autora, la pone en relación con el resto de sus obras y le permite llevar a escena una visión del mundo muy dieciochesca.

Palabras clave: Gálvez, teatro popular, comedia, siglo XVIII, siglo XIX, amazonas, mito, escritoras, género.

\section{ABSTRACT}

Las Esclavas Amazonas (1805) is the last original comedy written by María Rosa de Gálvez (1768-1806) and the only one in which the author adheres to the schemes of popular theater, which has caused a certain lack of interest in the work on the part of the critics, in contrast to other comedies and tragedies that are closest to Neoclassicism. Starting from the study of play's sources, this paper shows that while in their formal aspects Gálvez' comedy brings into play the resources of popular theater, the updating of the myth of the Amazon carried out by the work -which serves the gender claim underlying the author's dramatic production-, relates Las Esclavas Amazonas 
with other Gálvez' plays and allows her to stage a very distinctive worldview of the eighteenth century.

Keywords: Gálvez, popular theatre, comedy, XVIIIth Century, XIXth Century, amazon, myth, women writers, gender.

El 2 de noviembre de 1805, exactamente once meses antes de su fallecimiento, María Rosa de Gálvez (1768-1806) recibía la licencia para la representación de la que sería su última comedia original, Las Esclavas Amazonas, que se anunciaba sin embargo como obra traducida del francés. Con esta pieza cerraba la escritora malagueña una carrera dramática corta en el tiempo ${ }^{1}$-apenas cuatro años- pero cuantitativamente extensa si la comparamos con la de otras escritoras de su tiempo, compuesta de seis tragedias, dos piezas trágicas menores, cinco comedias originales y otras cuatro traducidas del francés ${ }^{2}$.

La comedia que nos ocupa, conservada en manuscrito ${ }^{3}$, nunca fue publicada. Sin embargo, y a diferencia de otras obras de la autora, se representó con cierto éxito, ya que tras su estreno el 4 de noviembre en el coliseo de los Caños del Peral, ese mismo mes se volvió a poner en escena en cinco ocasiones más, los días $(5,6,7,8$ y 20 de noviembre). Sabemos también que fue la

1. Aunque la escritora ya había realizado varias estancias en Madrid antes de esa fecha, Bordiga, en su biografía sobre Gálvez, señala 1800 como fecha más probable del traslado definitivo de María Rosa Gálvez a la Corte (2003: 26). Su producción dramática original se enmarca entre esa fecha y 1806: entre el 3 y el 10 de agosto de 1801 se representan su primera tragedia-Alí-Bek-y su primera comedia-Un loco hace ciento- en el teatro del Príncipe, mientras que en 1805 se representa su última comedia original, Las Esclavas Amazonas, y en 1806 la última traducida, La dama colérica o novia impaciente.

2. Las tragedias son Ali-Bek (Teatro Nuevo Español, 1801, vol. V), Florinda, Blanca de Rossi, Amnón, La delirante y Zinda (estas cuatro últimas publicadas en 1804 en sus Obras Poéticas, vols. II y III). Las piezas trágicas menores son el drama trágico en un acto Safo (representada en 1801; O.P., II) y la escena trágica unipersonal Saúl (O.P., II). Respecto a las comedias, las originales son Un loco hace ciento (Teatro Nuevo Español, 1801, V), La familia a la moda (representada en 1805), Los figurones literarios (O.P., I), El egoísta y Las esclavas Amazonas (representada en noviembre de 1805); las traducidas son Catalina o la bella labradora (Teatro Nuevo Español, V), La intriga epistolar (representada en agosto de 1802), Bion (O.P., I) y La dama colérica o novia impaciente (estrenada en 1806), que $\mathrm{M}^{\mathrm{a}}$ Jesús García Garrosa estudia en este mismo volumen.

3. En la Biblioteca Nacional se conservan dos manuscritos de Las Esclavas Amazonas. El 17196 presenta en portada el subtítulo «Comedia en tres actos en verso», mientras que en el manuscrito 16507, proveniente de la colección de Agustin Durán, aparece en portada el subtítulo de Hermanos descubiertos por un acaso de amor y la especificación de «Gran comedia». En este trabajo citaremos del manuscrito de Durán, que tiene 53 hojas y presenta correcciones de la mano de la autora. En la Biblioteca Municipal de Madrid se conserva también el manuscrito 28-14, que contiene al final diversos documentos relacionados con la obra, como la aprobación del Censor General de Teatros (de 31 de octubre de 1805) y la licencia eclesiástica de representación (de 2 de noviembre de 1805).

Anales, 23, 2011, pp. 95-126 
obra de Gálvez más representada después de su muerte ${ }^{4}$, dato que contrasta con el desinterés de la crítica contemporánea por esta comedia ${ }^{5}$, que resulta, al menos en lo formal, un tanto inusual en el conjunto de la dramaturgia de la autora malagueña.

De hecho, hasta la representación de Las Esclavas Amazonas en 1805, son evidentes los intentos de Gálvez por alcanzar reconocimiento como dramaturga. Se entrega al cultivo de los géneros valorados por los neoclásicos, como la comedia de costumbres o la comedia sentimental, e incluso otros menos habituales aún en la pluma femenina, como la tragedia bíblica, la de inspiración histórica o el drama, y en todos ellos se esfuerza con especial interés en tratar de compaginar el canon neoclásico con una temática que gira de forma casi monográfica en torno a la experiencia femenina en general y más particularmente a la posición de las mujeres en los inicios del siglo XIX (Establier, 2005). Como ya señalamos en otro trabajo sobre las comedias de Gálvez (Establier, 2006: 188), las cuatro que preceden a Las esclavas amazonas (Un loco hace ciento, Los figurones literarios, La familia a la moda y El egoísta) se presentan como un conjunto coherente, con una afinidad evidente en cuanto a su contenido y personajes, al «mensaje» o finalidad que persiguen y a los rasgos formales que comparten. En este sentido, todas ellas dramatizan diferentes aspectos de la cuestión matrimonial -tan cara a la comedia de costumbres neoclásica- y presentan desenlaces que se adecuan a la ortodoxia del pensamiento ilustrado, con el triunfo final del amor, de la conveniencia y del orden social; en las cuatro aparecen personajes femeninos que encarnan la razón y el buen juicio, a modo de muestrario del potencial de las mujeres para contribuir a la felicidad social; en todas ellas prevalece la intención didáctica, a través de la crítica de actitudes y vicios sociales varios (los excesos extrajerizantes, la vanidad pretenciosa y los desórdenes familiares), y también todas emplean en mayor o menor medida resortes dramáticos de gusto popular, que

4. Bordiga, a partir de los datos de Cotarelo, cita en su estudio sobre la autora al menos 9 representaciones más de Las esclavas amazonas entre 1807 y 1812 (2003: 113). Entre los documentos que figuran al final de la comedia en el manuscrito de la Biblioteca Municipal, se encuentra también licencia eclesiástica y civil de representación con fecha de mayo de 1817.

5. Julia Bordiga dedica a esta comedia cuatro páginas en su estudio sobre la autora (2003: 112-116), el más completo con el que contamos hasta el momento. Por su parte, Andioc le pasa sucinta revista en el prólogo a su edición de La familia a la moda (2001: 53-56), Elizabeth Franklin Lewis se ocupa brevemente de ella en el capítulo que dedica a Rosa de Gálvez en su trabajo Women Writers in the Spanish Enlightenment (2004: 106-111) y Catherine Flepp también la trata como parte de su trabajo sobre las ficciones de lo femenino en la obra de Gálvez (2006: 69-71). 


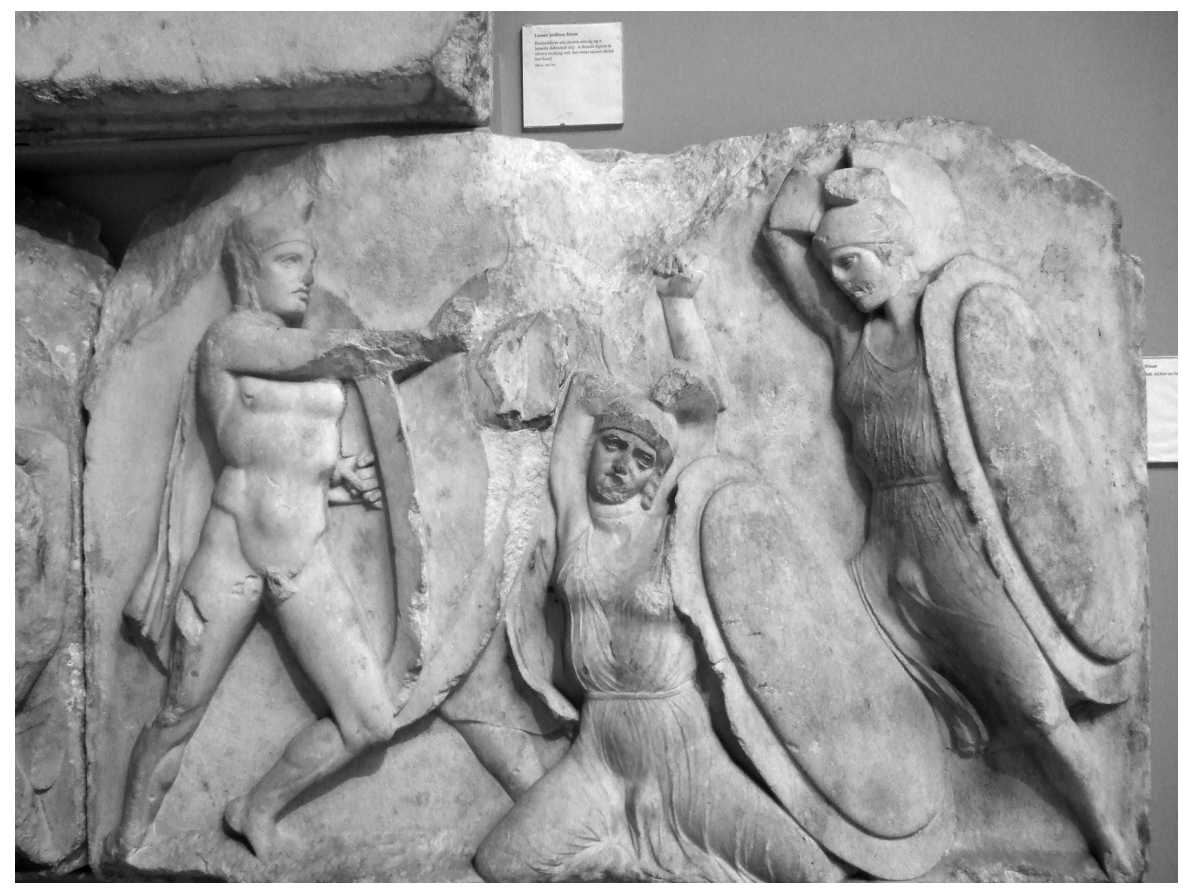

Relieve de la Amazonomaquia (Scopas, S. IV a de C.). Mausoleo de Halicarnasso.

se extienden desde el uso de ciertos procedimientos sainetescos al desarrollo en escena de lo sentimental.

Pese a esta inclinación hacia los recursos populares que Gálvez demuestra en sus comedias anteriores, lo cierto es que hasta la representación de Las Esclavas Amazonas se observa un interés por ceñirse a los esquemas dramáticos tolerados por el buen gusto o la práctica neoclásica, sea en la órbita de la comedia de costumbres (Un loco hace ciento, Los figurones literarios, La familia a la moda) o de la sentimental (El egoísta). Con Las Esclavas Amazonas, Gálvez renuncia por primera -y también última- vez a las coordenadas básicas de la comedia ilustrada -el didactismo, la verosimilitud, la proximidad espacio-temporal- para emprender una ruta dramática diferente, en la órbita del teatro mayoritario y de las reinterpretaciones dieciochescas de la comedia aúrea, y para ingresar definitivamente en esa nómina de autores a quienes, como señala Palacios, «la tiranía del público les obliga a salir del rigorismo formal de los fanáticos para buscar una línea intermedia en la que pretendan congraciarse con unos y con otros»(1996: 218). 
Las Esclavas Amazonas es, a primera vista, un disparatado popurrí de elementos y recursos propios de diferentes esquemas dramáticos del teatro popular de fines del XVIII, dentro del respeto a las unidades neoclásicas de tiempo (una sola jornada), lugar (el castillo de las amazonas en Siam) y acción: ambientación exótica, tema amoroso, mujeres aguerridas con aversión al matrimonio, héroes sensibles y razonables, criados astutos, música, canciones y demás parafernalia teatral, ambiente heroico, engaños y disfraces, pérdidas, reconocimientos y desenlace feliz. Las protagonistas de la comedia, Hipólita y Adelaida, son dos francesas convertidas en esclavas del rey de Siam y -curiosamente- a la vez en amazonas, dedicadas a la custodia del castillo en el que aquél guarda su serrallo. Las jóvenes, hijas de dos gobernantes de los fuertes franceses en Asia, fueron hechas prisioneras cuando aún no tenían uso de razón por unos piratas ingleses y compradas junto con la española Flora -viuda tras un ataque corsario al navío en el que viajaba con su marido hacia India- por un súbdito del rey siamés, el eunuco Emir, que las entregó como presente a su monarca con la esperanza de conseguir a cambio ciertas prebendas. Desengañado el monarca ante la esquivez de Hipólita, que defiende su honor a cualquier precio, oculta a las jóvenes su verdadero origen y las deja al cuidado de los dos eunucos, Emir y Abufar, para que se instruyan como amazonas en un castillo apartado de la corte. La acción de la comedia se inicia realmente cuando dos jóvenes franceses, el embajador Carlos Dorval y el oficial Alberto Dumenil, enviados por su gobierno para pactar la paz con el rey de Siam, llegan con sus tropas a los pies de los muros del castillo para liberar al sargento Trapantoja, que ha sido prendido por los soldados de Emir. Enterados los dos franceses de que allí moran las amazonas, esclavas del monarca siamés, deciden tratar de buscar entre ellas a sus respectivas hermanas, que fueron vendidas cuando los ingleses arrebataron a los franceses sus tropas en Asia, y en cuanto ven a Hipólita y a Adelaida, caen rendidamente enamorados de ellas. El acto segundo desarrolla el asunto de la esquivez de Hipólita, que ya había quedado planteado al final del anterior, y el de las estrategias de Carlos para vencerla. Trapantoja, que actúa de criado ingenioso y que asume las funciones teatrales del tradicional «gracioso», es quien urde el embrollo destinado a domeñar la altivez de Hipólita. Disfrazado del negro Candonga, logra introducirse en el castillo para ganar la confianza de la joven amazona y aplicarle un "caustico de zelos» (acto III, escena $5^{\text {a }}$ ) con que vencer su orgulloso desdén. Tras varios encuentros entre Carlos e Hipólita, en los que la esmerada galantería del francés se estrella contra la obstinada esquivez de la amazona, el enredo se resuelve en el acto III, en el que se Trapantoja-Candonga demuestra a Hipólita que sus celos eran infundados y se revela -contra la voluntad de 
Emir- la verdadera identidad de las jóvenes, que resultan ser las hermanas perdidas de Carlos y Alberto. El desenlace de este disparatado argumento es feliz, con reencuentro familiar, matrimonio doble -triple, si contamos con que Trapantoja resulta ser el marido que perdió Flora y que ambos se reconcilian al final de la obra- y humillación del eunuco malvado y misógino.

A los críticos del Memorial Literario, que publicaron su reseña sobre la obra el 31 de abril tras el estreno de la misma en el coliseo de los Caños, no les hizo gracia excesiva la comedia de Gálvez -que titulan erróneamente Las amazonas cautivas-aunque habituados a los atentados contra la verosimilitud y a los enredos del teatro popular de entresiglos, les pareció que «el giro de la acción no era violento, y que estaba bastante bien preparado»(Bordiga, 2003: 165). Sus censuras se centraron en dos puntos fundamentales: en primer lugar, la carencia de novedad del argumento, que venía a sumarse a una larga lista de «encuentros de hermanos largo tiempo separados; reconocimientos de esposos, de amigos, etc.» (Ibíd.) que sobresaturaban la escena de la época y neutralizaban, en opinión de los críticos del Memorial, el efecto teatral de la comedia de Gálvez; en segundo lugar, parecía incomodarles especialmente la obstinación de Hipólita en su rechazo a Carlos, que la convertía, a ojos de los críticos, en un carácter «exagerado, y demasiado fuera de orden» (Ibíd.), con actitudes poco creíbles en un personaje femenino, como el demostrar «tanta perseverancia en su dictamen, y mucho menos en materia de amor» (Ibíd.). Alababan, sin embargo, la correcta versificación, la propiedad en el lenguaje y la ejecución del decorado teatral.

María Rosa de Gálvez contestó en Variedades de Ciencias, Literatura y Artes con no poca indignación, arremetiendo sin concesiones contra los críticos que cuestionaban la verosimilitud de su heroína ${ }^{6}$ y reconociendo su comedia como fruto de las tensiones entre los gustos del público - cuyo plácet había buscado mediante la imitación de «las bellas escenas del Desdén, aunque en otras costumbres, y la inimitable versificación de nuestros poetas antiguos» (Bordiga, 2003: 166) - y las exigencias de los actores, razón última de que la obra, pese a ser original, se publicitara como traducida del francés ${ }^{7}$.

6. «¡O felices Adonis de nuestro siglo! ¡Cómo se conoce en vuestra explicación que no encontráis ninguna orgullosa amazona!, acaso la mía, a pesar de la educación que había formado su carácter, a vista de uno de vosotros se hubiera derretido; pero acaso también os hubiera hecho la mamola, y por esto cuidé de que el galán que había de rendir a mi heroína, tuviese figura de hombre» (Bordiga, 2003: 165)

7. Recordemos que en la temporada 1805-1806 se estrenaron en los coliseos madrileños 31 obras, una tercera parte de las cuales consiste en traducciones del francés. En general, desde el cambio de siglo hasta 1808 la escena madrileña está atenta al movimiento cultural europeo, y las versiones del francés, con una excelente acogida por parte del público, 


\section{DE AMAZONAS, ESQUIVAS Y OTRAS FUENTES}

Desde que hace casi 2800 años Homero describiera una raza de mujeres iguales a los hombres en el campo de batalla (las amazonas antianeirai de la Iliada), y que Eurípides (Hipólito) y Esquilo (Las suplicantes) las llevaran a la tragedia unas centurias después, estas guerreras míticas, bárbaras e indómitas, mezcla de virgo y de virago, han ejercido una notable fascinación en casi todas las etapas de la historia literaria occidental hasta nuestros días. Sea cual sea el marco geográfico -el Cáucaso, Asia Menor, el África blanca o negra, India o Hispanoamérica- y el momento histórico en que se las encuadre -desde la guerra de Troya a la mismísima conquista americana-, o el episodio mítico que se ponga en juego -Hipólita y Heracles, Teseo y Antíope, Aquiles y Pentesilea, Talestris y Alejandro Magno, el asalto a Atenas, la guerra de Troya, etc.- al menos cuatro constantes caracterizan a las amazonas a lo largo de esa nutrida representación literaria: 1) su poder - detentan un poder «femenino» y autónomo en una sociedad absolutamente ginecocrática; 2) su coraje en el campo de batalla -manejan las armas como los hombres y les es necesaro batirse para conservar el estatus amazónico-; 3) su independencia sexual -disponen libremente de su cuerpo, sea para conservarse vírgenes, sea para elegir compañero en el encuentro amoroso-; 4) y por último, su obligada sumisión final a la norma patriarcal: sea como sea, las amazonas son vencidas militarmente o seducidas en el ámbito íntimo por un varón, y así, la amenaza que supone para la comunidad política la autonomía y el poder biológico de las amazonas queda en los textos anulada, neutralizada, sustituida por un orden masculino reestablecido tras un episodio temporal de inversión ${ }^{8}$.

Desde el Renacimiento hasta principios del XIX la escena europea se recreó en este esquema. Cierto es que celebró a las amazonas cuando tuvo necesidad de exaltar a las reinas aguerridas, como ocurre en la Inglaterra isabelina, que rinde culto a su reina virgen, capaz de cabalgar hasta Tilbury para arengar a la flota inglesa ante la amenaza de la Armada Invencible; recordemos, por ejemplo, a la Hipólita de A Midsummer Night's Dream y a otras amazonas menos explícitas en la obra de Shakespeare, como Juana de Arco en Henry VI o Katherina en The Taming of the Shrew. Pero en general, la puesta en escena de sociedades ginecocráticas o reinos de mujeres conducía en la mayor parte de

son muy abundantes (Saura, 2008: 218), lo cual explica la concesión de $\mathrm{M}^{a}$ Rosa Gálvez al hacer pasar su comedia como traducción.

8. Sobre el mito de las amazonas, ampliamente estudiado desde la filosofía, la historia, la psicología y la antropología, son imprescindibles, además de la historia clásica de Guyon (1740) y del conocido texto de Bachofen (1861), los estudios de Tyrrell (1989), Samuel (1975), Block (1995), Pastre (1996), Borgeaud (1999) y Leduc (2008). 
los $\operatorname{casos}^{9}$ a la celebración del poder patriarcal y a la domesticación de la amazona indómita e inquietante, que solía terminar por aceptar las obligaciones del matrimonio heterosexual.

El tratamiento del tema es muy similar en el teatro español de los siglos XVII y XVIII. Bien es cierto, no obstante, que a diferencia de lo que ocurre en el ámbito europeo, que dramatiza recurrentemente el asunto amazónico ${ }^{10}$, el teatro español anterior a Las Esclavas Amazonas no muestra especial inclinación hacia el mito de las legendarias guerreras. Ni siquiera la comedia aúrea, tan proclive a llevar a las tablas diferentes muestras de «mujeres varoniles»,

9. Desde luego, también existen algunos ejemplos de inversión del mito, como las tragedias de Von Kleist Pentesilea (1808) y de Anne-Marie du Boccage Les Amazones (1748), aunque son casos contados en el XVIII. Con Las amazonas, Madame du Boccage inaugura un ciclo de inversión del mito amazónico muy productivo en las reinterpretaciones del siglo XX. Frente a las versiones «oficiales» del mito, según las cuales Teseo fue vencedor de las amazonas y seductor $-\mathrm{y}$ a veces violador- de Antíope, en la obra de Boccage el héroe es prisionero de las guerreras, admirador de su superioridad y ardiente enamorado de Antíope. No en vano se atribuyó el epíteto de «amazona» a su autora. Por su parte, sesenta años más tarde Kleist invierte en Pentesilea (1808) el enfrentamiento entre Aquiles y Pentesilea, y convierte a ésta en artífice del asesinato del que es víctima según la tradición legendaria. Al llegar el siglo XX, estas inversiones que transforman a las amazonas en vencedoras -temporales, por lo general- del héroe se multiplican, no sólo desde la literatura feminista, sino también desde el cine o el cómic. Remito para esto al trabajo que coordina Leduc (2008).

10. Aunque resulte inviable recoger aquí todas las muestras del interés del teatro europeo de esta época por el tema amazónico, recordaremos algunos ejemplos: en la escena estuardiana, dos tragicomedias llevan a las tablas los estados gobernados por amazonas: The Lady Errant (1635-6) de William Cartwright, y The Sea Voyage (1662), de John Fletcher y Philip Massinger; en Italia, ambientada en la corte de Hipólita, reina de las Amazonas, se representa en 1672 Il Schiavo di sua moglie, ópera en tres actos de Francisco Provenzale. Mientras, en Francia, en octubre de 1699, el futuro Felipe V asiste en Fontainebleau — corte de su abuelo Luis XIV— al estreno de la nueva ópera de Destouches, Marthésie, première Reine des Amazones, tragedia en cinco actos con libreto de Antoine Houdar de La Motte. En 1720 se representa en el teatro de la Foire Saint-Laurent la ópera cómica en un acto de Lesage L'Ile des Amazones, con música de Jean-Claude Gilliers. Siete años más tarde, en 1727, se representa la comedia en 3 actos de Marc-Antoine Legrand y Louis Fuzelier Les amazones modernes, que sirvió además de inspiración a un conocido sainete de Ramón de la Cruz que cito más adelante. En 1749 se representa la citada tragedia en 5 actos de Madame du Boccage Les Amazones, y apenas un año más tarde Marivaux publica en el Mercure de France la obra La colonie, una nueva versión de su obra de 1729 La nouvelle colonie, comedia social y filosófica en la que plantea la posibilidad de un gobierno de mujeres al estilo de la república amazónica. En Alemania, Louise Gottsched adapta en 1760 el libreto Thalestris de Marie-Antoinette de Saxe para poner en escena el amor prohibido entre los Escitas y las Amazonas, en 1806 publica Franz Von Holbein Mirina, reina de las amazonas y en 1808 Von Kleist dramatiza en Pentesilea el duelo fatal de amor entre la reina de las amazonas y el mítico Aquiles. 
deleitando a su público con féminas belicosas capaces de liderar revueltas y levantamientos armados, bandoleras y cazadoras, nos ha legado una representación contundente de estas míticas amazonas con tanto potencial dramático.

Lope de Vega, en su catálogo de comedias mitológicas, dejó dos obras dedicadas al asunto amazónico ${ }^{11}$ : Las mujeres sin hombres y Las justas de Tebas y reina de las Amazonas. La primera, que se publicó en 1621 en la Decimosexta parte de las comedias lopescas, es el origen de la mayor parte de las reinterpretaciones que de la leyenda hizo el teatro de los siglos XVII y XVIII. La obra toma su asunto de las fuentes clásicas, tal como confiesa el propio autor en su dedicatoria «A Marcia Leonarda» (seudónimo poético de Doña Marta de Nevares); Diodoro Sículo, Justino, Arriano y Jenofonte le proporcionan las coordenadas fundamentales para plantear el asunto dramático: un estado absolutamente ginecocrático gobernado por amazonas en la clásica ciudad de Temiscira, el adiestramiento de aquéllas en el arte de la guerra, la aniquilación de los varones, la batalla de Teseo contra las amazonas y su victoria sobre su reina Antiopía, que Lope convierte por cierto en un triunfo amoroso. En Las mujeres sin hombres, de hecho, el enfrentamiento de los griegos (Teseo, Hércules y Jasón) y las amazonas (Antiopía, Menalipe, Deyanira e Hipólita) es una auténtica guerra de amor; las amazonas resultan ser menos esquivas de lo que declaran públicamente y caen rendidas ante los encantos masculinos de Teseo. El tratamiento de las leyes sobre las que descansa el gobierno femenino de Temiscira es en la obra absolutamente burlesco, y las relaciones entre las amazonas ratifican por medio de la sátira todos los tópicos clásicos sobre las mujeres (envidia, rivalidad, predominio de lo privado sobre los intereses públicos, volubilidad...). Al final se impone la visión lopesca de la auténtica naturaleza femenina, triunfa el amor y por ende la felicidad general: «Claro está que el valor de mujeres determinadas sólo con la blandura del amor podía ser vencido» (377).

No hay discrepancia entre Las mujeres sin hombres y Las justas de Tebas y Reina de las Amazonas en cuanto al mensaje de armonía final entre los sexos. En esta última obra, cuyo enredo es tan complejo como disparatado, se entrecruzan dos historias: la de la princesa de Tebas, Délbora, que va a ser ofrecida en matrimonio a quien resulte ganador de las justas que en su ciudad se celebran, y la de la reina amazona Abderite, que acude al torneo en busca de su

11. Dejamos aparte Las grandezas de Alejandro, a pesar de que en la obra aparecen algunas amazonas (Tamira, Lisandra y Rojane, que desea engendrar un hijo -una hija, si atendemos a la leyenda- de Alejandro Magno para dar continuidad al reino «como es costumbre amazona» [36]), ya que su brevísima intervención en la obra es irrelevante para el desarrollo de la tragicomedia.

Anales, 23, 2011, pp. 95-126 


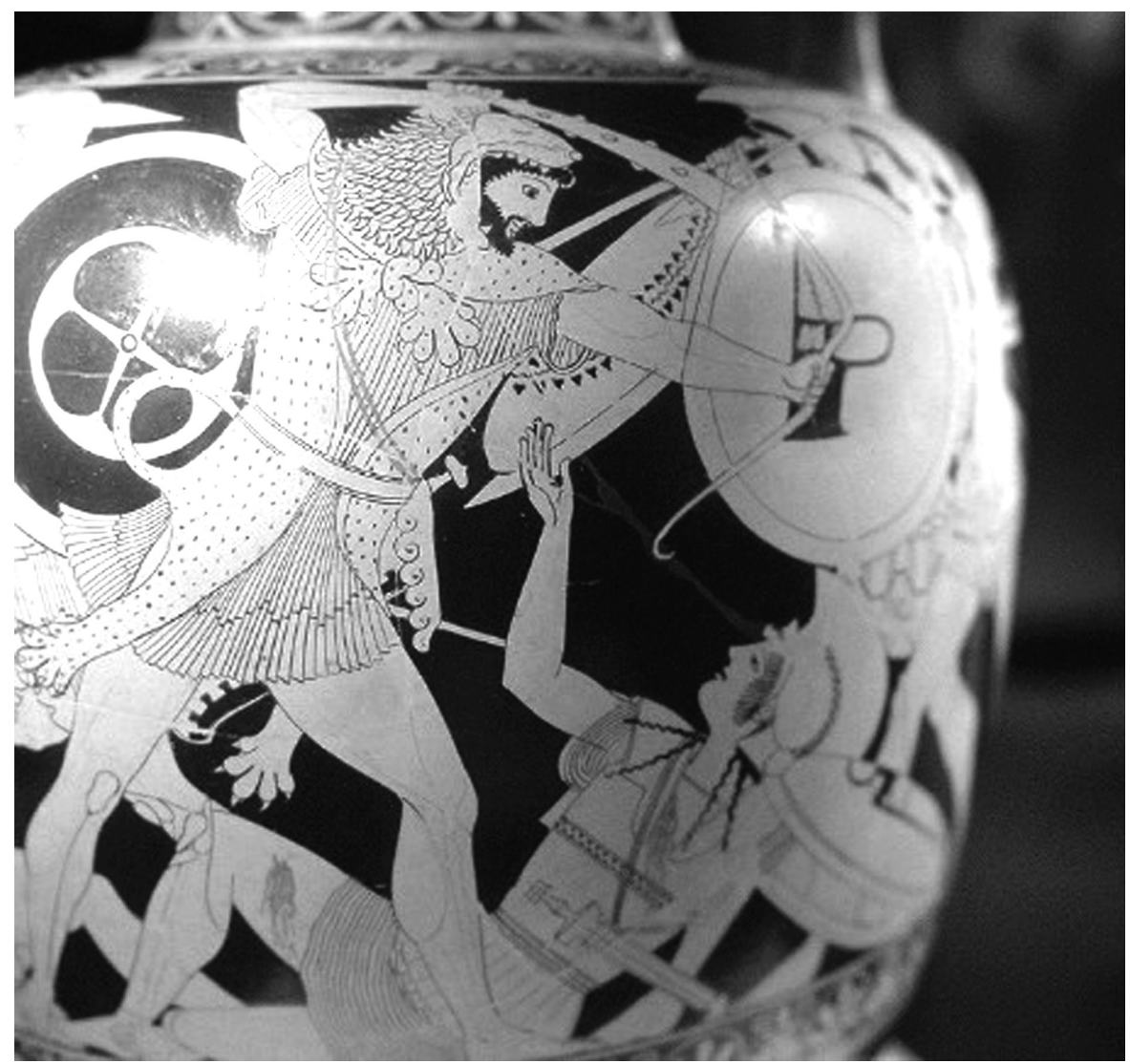

Jarron griego: batalla entre Hércules e Hipólita, reina de las Amazonas.

hermano Jelando pero se enamora perdidamente de Ardenio, pretendiente a su vez de Délbora. Abderite, disfrazada de hombre, se ve obligada a enfrentarse a Sergesto, hermano de Ardenio, y acaba con su vida. Por su parte Ardenio, que ha tomado también una identidad falsa -la de Belardo-, mata a Jelando en venganza por la muerte de su hermano. La amazona sale vencedora de las justas, recibe la mano de la princesa y la ofrece a Ardenio, aunque finalmente éste y Abderite se perdonan mutuamente la muerte de sus respectivos hermanos y terminan la obra como amantes. Una vez más, se restablece el orden natural de las cosas cuando Abderite deja de hacer gala de una masculinidad impostada, depone su actitud agresiva y abandona el disfraz de hombre para aceptar el amor de Ardenio y el matrimonio consiguiente: «iBuen hermano 
me mataste» -reconoce la amazona, ahora ya bastante menos indómita que al principio de la comedia- «mas buen marido me diste!» (813).

En la dramaturgia posterior a Lope de Vega no parece interesar excesivamente el tema amazónico. Las Amazonas en las Indias ${ }^{12}$, de Tirso de Molina, funde el mito clásico sobre las guerreras de la Capadocia con la vieja leyenda indiana de las Amazonas en el Nuevo Mundo impulsada por la Relación ${ }^{13}$ que escribe Fray Gaspar de Carvajal tras su viaje con Orellana a través del gran río en 1542. En realidad, la obra se centra en el asunto de la muerte de Gonzalo de Pizarro en el Perú, y la aparición de las amazonas Menalipe -enamorada de Pizarro- y Martesia es más ornamental que otra cosa. Más allá del principio del primer acto, en el que las amazonas aparecen pertrechadas de tales, portando los adminículos para la guerra propios de su condición (hachas, bastones, arcos y flechas a la espalda) y luchando contra los españoles que se aventuran en lo más intrincado del gran río que lleva su nombre, el resto de sus intervenciones, más bien escasas, en los actos II y III de la obra, nada tiene que ver con su particular condición de guerreras legendarias, correspondiendo más bien a las de cualquier mujer enamorada que sufre la ausencia de su amado, le recrimina su traición y trata a toda costa de evitar su muerte, como le ocurre a Menalipe con Gonzalo Pizarro.

Bastante más cercanas a la leyenda clásica son las amazonas de Antonio de Solís en Las Amazonas de Escitia (1657) ${ }^{14}$ (también publicada como Las amazonas y confundida en ocasiones con Las amazonas de España de Cañizares (1720) y con Las amazonas de España y prodigio de castilla, de Juan del

12. Las Amazonas en las Indias forma parte, junto a Todo es dar en una cosa y La lealtad contra la envidia, de la llamada Trilogía de los Pizarros, escrita por Tirso para reivindicar el nombre de los Pizarro y su participación en la conquista del Perú. La obra se publicó por primera vez en la Cuarta parte de las comedias del maestro Tirso de Molina (Madrid, María de Quiñones, 1635) y es la única de la trilogía a la que Tirso denominó tragedia (Romanos, 1998: 290)

13. La Relación del nuevo descubrimiento del famoso Río Grande que descubrió por muy gran ventura el Capitán Francisco de Orellana fue escrita por Fray Gaspar de Carvajal, el capellán que acompañó a Orellana en su exploración del Amazonas. Cuenta allí Carvajal que la expedición fue atacada por feroces mujeres guerreras, similares a las amazonas de la mitología griega. Partes de la Relación, responsable también del mito de El Dorado, fueron recogidas en la Historia general y natural de las Indias (1542), de Gonzalo Fernández de Oviedo, publicada completa por vez primera en 1895 por el erudito chileno José Toribio Medina.

14. Se publicó en 1657 en Escogidas IX con el título Las amazonas, y en 1681 con el título completo en Comedias de Don Antonio de Solís y Rivadeneyra. Se representó el 7 de febrero de 1655 por vez primera (Varey y Shergold, 1989: 55). 
Castillo $(1701)^{15}$. La comedia de Solís añade poco a la reinterpretación lopesca de la leyenda amazónica: la reina Menalipe gobierna el «invicto Imperio de las Amazonas, este bien repetido portento de marimachos» (Solís: 3) desde la absoluta animadversión a los hombres. Al final de la obra y tras una considerable dosis de enredos, Menalipe y Miquilene, una de las rivales que le disputa la corona, terminan respectivamente enamoradas de Polidoro -príncipe de los sármatas, en guerra con las Amazonas- y de Astolfo (hijo de la mítica reina amazónica Talestris y de Alejandro Magno), y truecan de buen grado los gritos de «Mueran los hombres» (Solís: 30) por los de «Vivan los hombres, las mujeres vivan» (Solís: 32). En la estela de Lope, el amor consigue deponer la altivez de las amazonas, Escitia y Sarmacia se funden en uno solo, y las mujeres indómitas vuelven gustosas al lugar que les correspondía. Las amazonas de Solís, que encajan a la perfección en el modelo de la comedia aúrea (la obra no es sino una comedia de enredo con mujeres esquivas) tuvieron su eco en la literatura de $\operatorname{cordel}^{16}$ y lo cierto es que no dejaron de llevarse a escena hasta principios del siglo XIX ${ }^{17}$.

Aunque guarda notables concomitancias con la de Solís, más original resulta el tratamiento del tema en Las amazonas de España, innovador «dramma musical» al estilo italiano (Carreras, 1996: 54) con libreto de José de Cañizares y música del compositor veneciano Giacomo Facco. La obra se inspira en un pasaje de Plutarco que describe el paso de Aníbal por los Pirineos y su encuentro con mujeres guerreras, y une este episodio al tema mitológico de las amazonas, exaltando las figuras de Aníbal y de Marfilia (la reina de las amazonas). Se estrenó el 22 de abril de 1720 en el Coliseo del Buen Retiro de Madrid, como parte de las celebraciones ideadas por Isabel de Farnesio, gran amante de la ópera italiana, con motivo del nacimiento del infante Don Felipe de Borbón, y supuso el comienzo de una serie de espectáculos

15. La obra de Juan del Castillo poco tiene que ver con el tema que nos ocupa. Lejos de la escenificación del mito ateniense, las «amazonas» de esta obra son nada menos que las damas castellanas, que, espada en mano y acaudilladas por Doña Sancha de Navarra (esposa del Conde Fernán González), auxilian a las tropas cristianas en defensa de la fe.

16. La obra dio lugar a dos pasillos de comedia con idéntico contenido pero diferente título Coloquio de Las Amazonas. Relación de don Eugenio Gerardo Lobo a una dama de Zaragoza. (s.l.: s/i., s.a.) y Pasillo de Las Amazonas. (Málaga: Félix de Casas y Martínez, s.a.). Reproducen el diálogo central de la jornada segunda de la comedia entre Miquilene y Astolfo. El diálogo constituye la peripecia de la comedia, cuando estos dos personajes se encuentran y se enamoran instantáneamente (Literatura de cordel y teatro en España).

17. Andioc y Coulon (1997: II, 621) citan al menos una representación por temporada entre 1708 y 1721. También recogen representaciones de Las amazonas de Escitia en 1787 (02/XI), 1793 (19/IV y 29/XI), 1795 (15/IV), 1798 (15/I) e incluso 1802 (22/V). 
dramático-musicales organizados por la Villa en honor de la Corona. Fue representada casi una veintena de veces más ese mismo año y volvió a los escenarios en 1724 en el Corral de la Cruz los días 30 de julio y 6, 10, 13, y 15 de agosto. También formó parte de los festejos para los desposorios reales de los príncipes de Asturias, los futuros reyes de España, Fernando VI y María Bárbara de Braganza, el 18 de enero de 1728 en Lisboa (López Alemany y Varey, 2006: 15-22).

El tema, como vemos, no resultaba extraño al público de Madrid. De hecho, con el título de Las amazonas, que bien podría corresponder a cualquiera de las citadas, los coliseos de la capital albergan al menos una treintena de representaciones entre 1725 y 1783 (Andioc y Coulon, 1997, II: 620). No sorprende que en 1772 Ramón de la Cruz se deje caer con un sainete, La república de las mujeres, donde a base de satirizar la vieja leyenda amazónica, aprovecha para cuestionar la posibilidad de cualquier proyección pública para las mujeres. Las amazonas del sainetero madrileño no son sólo débiles ante el amor, como las de Lope, Tirso o Solís; son vanidosas, coquetas, irresponsables, envidiosas y crueles con los hombres. Su república es un auténtico estado del desgobierno, que demuestra la peligrosa esencia del poder en manos femeninas. La pieza, que es una adaptación de la disparatada comedia en tres actos de Legrand Les amazones modernes $(1770)^{18}$, apareció de nuevo con el mismo título en español -Las amazonas modernas- en el catálogo que realizó Ramón de la Cruz en 1785 con el objeto de obtener licencia de impresión para su teatro (Coulon, 1989: 8).

Como hemos visto, no eran muchos los modelos autóctonos a los que María Rosa de Gálvez pudiera haberse acogido a la hora de llevar a las tablas el tema de las amazonas. Sin embargo, sabemos a ciencia cierta que a la autora le interesaba el teatro francés -había sido traductora de éste en cuatro ocasiones $^{19}$-, y que éste había mostrado cierta inclinación por el asunto que nos ocupa $^{20}$, así que no podemos descartar que, además de inspirarse en los modelos del teatro popular nacional del XVIII, Gálvez pudiera conocer el tema por la ópera de Lesage, la tragedia de Legrand o incluso por la más atrevida de Madame du Boccage.

Por otro lado, lo cierto es que las protagonistas de Gálvez no guardan gran parecido con las de sus predecesores en la escena española. Las esclavas amazonas son inofensivas, y aunque salen a escena pertrechadas con la indumentaria y los adminículos amazónicos, pocas muestras dan a lo largo de la

18. Ver nota 10

19. Ver nota 2.

20. Ver nota 10 .

Anales, 23, 2011, pp. 95-126 
obra de furor guerrero, como las de Lope, Solís o Tirso, y tampoco hacen gala de especial agresividad hacia el contigente masculino, como las de el sainetero madrileño. El núcleo argumental de la comedia de Gálvez lo ocupa más bien la reticencia de Hipólita -no así de Adelaida y Flora- al amor y al matrimonio, y más allá de unas cuantas amenazas a los oficiales franceses, lo cierto es que esta amazona esclava ejerce más de dama esquiva atenta a los galanteos de Carlos que de guerrera despiadada y enemiga acérrima de los hombres, como buena parte de sus predecesoras. Y precisamente de eso, de esquivas desdeñosas, no le faltaban a la autora modelos en la tradición nacional, no en vano son las más numerosas de cuantas mujeres varoniles nos ha legado nuestra comedia áurea.

El tipo de la esquiva, bien estudiado por M.Mckendrick desde sus manifestaciones embrionarias en el teatro prelopesco ${ }^{21}$, fue popularizado por el dramaturgo madrileño y consagrado después por Moreto y Calderón. Se caracteriza por su pertinaz aversión al amor, al matrimonio y en ocasiones incluso a los hombres. Por lo general la esquivez de la dama puede tener su origen en la vanidad, en el orgullo o en el temor de aquella que la padece a sacrificar la independencia personal o a equivocarse en la elección de la pareja, pero incluso en los casos de renuncia al amor más fundamentados en la razón o en el sentido común, la mujer desdeñosa -en rebeldía contra su propia naturaleza «femenina», contra el orden establecido y el armónico fluir de las relaciones intersexuales- no deja de constituir un especimen incómodo para el estatu quo y debe, por tanto, ser reconducida por la buena senda. Así, las comedias de Lope de Vega que abordan el asunto de la esquivez femenina establecieron una suerte de esquema dramático en el que, partiendo de una situación inicial de aversión al amor y al matrimonio, los desprecios -generalmente fingidos- del amante rechazado y la vieja artimaña de los celos conseguían despertar gradualmente los sentimientos amorosos de la heroína, que culminaba este proceso al final de la comedia en una entrega voluntaria al insistente enamorado, haciendo coincidir el orden natural de las cosas con el buen orden dramático.

No son pocas las comedias de Lope con mujeres esquivas, arrogantes y vanidosas que se reconcilian con el amor, como ocurre en Los milagros del desprecio, La moza de cántaro, La fe rompida, La varona castellana, El soldado amante o La vengadora de las mujeres, y tampoco es de extrañar, como bien

21. McKendrick (1974: 45 y stes) señala, entre los predecesores de Lope que esbozan en sus obras el personaje de la heroína esquiva, a Gil Vicente, y más indirectamente a Cristóbal de Virués, Guillén de Castro, Francisco Agustín Tárrega, Gaspar de Aguilar o el propio Cervantes. 
señala McKendrick, que este esquema lopesco, que incluye ineludiblemente el rendimiento final de la fémina, triunfara entre el público masculino -reforzado en su autoestima- e incluso entre el femenino -al que agradaban los finales felices con matrimonio incluido-, y se convirtiera en una convención más en el teatro áureo (1974: 320-322). Así, por ejemplo, diversas obras de Calderón (No hay burlas con el amor, Mujer, llora y vencerás, Afectos de odio $y$ amor), de Tirso (El vergonzoso en palacio, El burlador de Sevilla), de Rojas Zorrilla (Sin honra no hay amistad, Lo que son las mujeres), o de Moreto (El desdén, con el desdén, Hacer remedio el dolor) incluyeron entre sus heroínas -o entre sus personajes secundarios femeninos- esquivas y desdeñosas de diverso calado. Sólo una mujer, la dramaturga Ana Caro, se atreve en el XVII a convertir en protagonista de El conde Partinuplés a una mujer desdeñosa, la princesa Rosaura, que se niega a contraer matrimonio por una profecía de su propio padre, pero acaba, como todas las demás, unida al conde ${ }^{22}$. Tengamos en cuenta que una buena parte de las citadas se seguía representando en la primera década del XIX, nada más llegar María Rosa de Gálvez a la Corte ${ }^{23}$, especialmente las tres de Calderón, La moza de cántaro en refundición de Trigueros y El desdén de Moreto ${ }^{24}$.

Los escasos estudios que se han interesado en Las esclavas amazonas suelen coincidir en señalar El desdén, con el desdén como fuente principal de la comedia de Gálvez, probablemente siguiendo las pistas que ofrece la propia autora. Cierto es que, a diferencia de la mayoría de las comedias del Siglo de Oro, que no suscitaban excesivo entusiasmo entre el público de la centuria siguiente (Andioc, 1987:13-26), las obras de Moreto, especialmente El desdén, gozaron de gran aceptación en las primeras décadas del XVIII, y aunque el número de representaciones se redujo conforme se popularizaba una nueva manera teatral más acorde con los gustos dieciochescos, consiguieron mantenerse en el candelero hasta principios del siglo siguiente ${ }^{25}$. De hecho, entre

22. No hay noticia de que la comedia de Ana Caro, impresa en 1653, se representase nunca. Existe edición moderna de la obra (Delgado, 1998).

23. Ver nota 1.

24. Ver Andioc y Coulon (1997, II: 613, 733, 784, 786, 875). Respecto a El desdén con el desdén, los estudiosos citan varias representaciones entre el cambio de centuria y 1805 , todas ellas en el Teatro de la Cruz: los días 21/IV/1800, 28/IX y 22/X de 1802, 26/I/1803 e incluso el 14/IV/1805, en la misma temporada en la que se estrenó Las esclavas amazonas (Andioc y Coulon, 1997, II: 687).

25. Sobre la popularidad de Moreto en el XVIII, ver Davis (1991:191-204). Según los datos que se ofrecen en este estudio, entre 1708 y 1719 hubo 213 representaciones en Madrid de 17 obras distintas de Moreto. En lo que respecta a El desdén, entre 1708 y 1718 esta obra llegó a alcanzar la cifra de 33 representaciones en los corrales de Madrid (Varey y Davis, 1992: 389). Siguió habiendo numerosas representaciones de la obra en Madrid a 


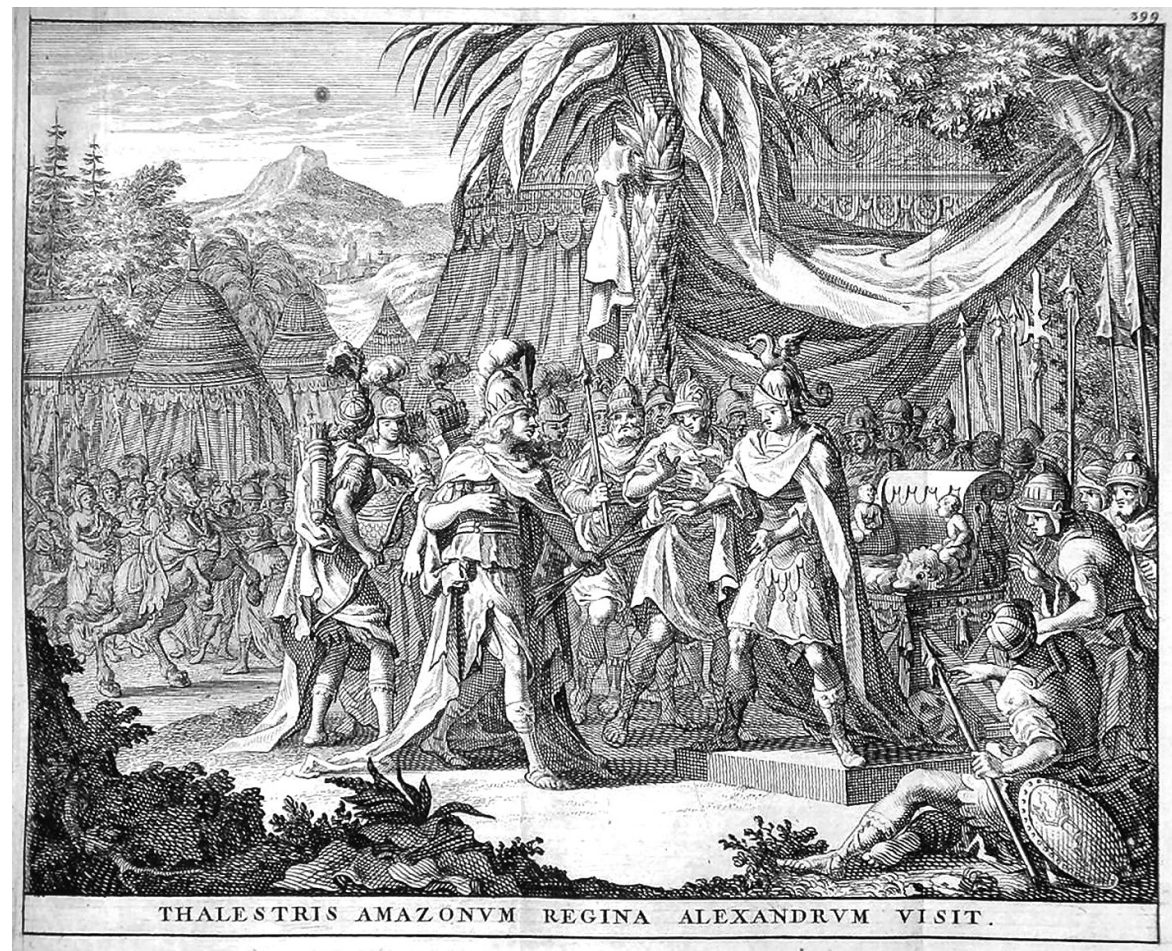

Thalestris, reina de las Amazonas, visita a Alejandro Magno (Edición holandesa de La vie d'Alexandre de Claude Favre de Vaugelas, 1696).

1801 y 1806, años en que se concentra la actividad dramática de María Rosa de Gálvez, El desdén aún seguía representándose con cierto éxito en España y

finales de siglo y principios del siguiente (Coe, 1935:64-65), así como en otros lugares de España (Toledo, Valencia, Valladolid, Barcelona, Sevilla,...) y del extranjero (Méjico, Brasil, Ecuador, Chile), llegando incluso a tener edición novohispana (Hernández Reyes, 2008: 223). Sobre la popularidad de El desdén con el desdén en el XVIII y en el XIX, conviene consultar los trabajos de Mackenzie (1994), especialmente las notas 25 (23-24) y 14 (163-4), y de Castañeda (1974:142-148).

Recordemos también que además de recibir una excelente acogida por parte del público, esta comedia es alabada por Luzán, recogida en 1767 por Bernardo de Iriarte en su «Lista de comedias escogidas y corregidas para los dos teatros de la Corte» (Palacios Fernández, 1990: 61) y aceptada en general por los críticos neoclásicos y románticos (Castañeda, 1974:142-3; Checa, 1990:31). 
llevaba ya varias adaptaciones en el extranjero ${ }^{26}$. Considerando que Las esclavas amazonas supone la primera y única tentativa de la autora malagueña en una fórmula dramática de reconocida aceptación popular, no resultaba descabellado tomar como fuente de inspiración una obra como la de Moreto, que había dado tanto juego a lo largo de más de un siglo y que parecía conciliar los gustos del público con el beneplácito de la crítica neoclásica.

Las similitudes entre ambas obras saltan a la vista, pero se quedan en lo meramente superficial. La Diana de Moreto es reticente al amor, como Hipólita, y lo es por motivos similares en su esencia (temor al yugo del matrimonio), el Carlos de El Desdén es tan obstinado a la hora de conseguir a su amada como el de Gálvez y los dos cuentan con la ayuda de un criado-gracioso (Polilla, Trapantoja) que mediante el engaño y el uso del disfraz propicia o facilita el acercamiento del enamorado a la dama desdeñosa; la fobia al amor de las heroínas se vence en ambas obras aplicando el viejo principio homeopático del similia similibus curentur, de manera que la conjunción del aparente desdén del galán y los celos es el detonante de la conversión al amor de Diana y de Hipólita. Desde luego, los finales de las dos comedias coinciden y todos los personajes -graciosos incluidos- encuentran a su media naranja.

Por lo demás, poco en común guardan las dos obras. Sin entrar en un cotejo detallado de las dos comedias ni insistir en las obvias diferencias argumentales ${ }^{27}$, es obvio que nada tiene que ver el ambiente refinado de comedia palaciega presente en El desdén, con sus espacios aristocráticos -el palacio condal-, sus entretenimientos cortesanos, y sus personajes de la alta nobleza catalana que bailan, se cortejan entre sí y discuten de asuntos socio-políticos, con el exotismo descabellado y superficial de las amazonas, los piratas secuestradores, los eunucos negros y los soldados franceses con los que Gálvez construye la trama de su comedia a imagen y semejanza del teatro popular de su tiempo. Tampoco coinciden los motivos del asunto central de las dos obras, la esquivez de sus protagonistas, siendo Diana una dama instruida, heredera de una corona, que renuncia al amor como conclusión de sus estudios y lecturas sobre el tema y que expresa su determinación en términos de absoluta abstracción, e Hipólita por el contrario una esclava, secuestrada desde la infancia en un país exótico, quien asocia a los hombres con el engaño, la violencia y la opresión. Desde luego, absolutamente dispar es el enfoque que presentan los

26. Ver Andioc y Coulon, 1997, II: 687). Para las adaptaciones extranjeras de la obra, ver Castañeda (1974: 83).

27. Para El desdén, con el desdén, ver Caldera (1960), Castañeda (1974), Mackenzie (1994) y las introducciones de las ediciones críticas de la obra preparadas por Rico (1971) y por Varey (1999). 
dos dramaturgos, Moreto y Gálvez, de la esquivez femenina: si en El Desdén aparece como fruto de un error intelectual, que se censura explícitamente y se corrige aplicando a la vanidosa un oportuno baño de humildad, en la obra de la autora malagueña la esquivez de Hipólita es consecuencia natural de la posición de inferioridad que las mujeres ocupan en el mundo y se resuelve, como veremos, de una forma mucho más «dieciochesca» y a la vez más acorde con la ideas de Gálvez sobre su propio género.

Resumamos pues señalando que aunque el esquema básico de las dos comedias sea el mismo -el de Lope, al fin y al cabo: enamoramiento del galán, negativa de la esquiva, crisis y resolución positiva del conflicto-, y aunque la obra de Gálvez responda también, como la de Moreto, a la pregunta que se encuentra en la base de las obras lopescas de esta temática, a saber, cómo es posible doblegar la voluntad de una mujer esquiva, Las Esclavas Amazonas lo hace desde la óptica de una dramaturga con absoluta conciencia de su condición sexual y desde las tendencias propias del teatro de entresiglos.

\section{LAS AMAZONAS DE GÁLVEZ: LA REINTERPRETACIÓN FEMENINA DEL MITO EN EL TEATRO POPULAR DE ENTRESIGLOS}

Tal como señalé más arriba, Las Esclavas Amazonas es una muestra inmejorable de ese hibridismo que caracteriza el teatro popular de finales del XVIII y de principios de la centuria siguiente, y que convierte en tarea ardua la de adscribir esta obra de Gálvez -y otras de la misma autora que se sirven también en mayor o menor medida de los esquemas del teatro mayoritario- a un género concreto.

Pese a que en ocasiones se la ha tratado como «comedia heroica» (Bordiga, 2003:112), lo cierto es que la obra se encuentra mucho más cerca del teatro «romancesco», es decir, con argumento de acción, aventuras y sentimientos (Palacios, 1996: 142) que del «espectacular», tratándose de una comedia sencilla en la que predomina en todo momento el desarrollo del nudo argumental -la cuestión amorosa y la intriga acerca del vínculo que une a los protagonistas- sobre el alarde escenográfico en que se recrean las comedias «de teatro». Presenta, desde luego, algunos efectos escénicos propios de las comedias militares tan en boga en las últimas dos décadas del XVIII -aunque en este caso tengan una función puramente «decorativa»-, como la vistuosidad en el vestuario (imaginemos el exotismo con el que irían ataviadas las amazonas o Emir, por ejemplo) o la presencia de armas en el escenario (las acotaciones nos indican en el acto I que los soldados de Emir salen a escena pertrechados con sables y otras armas; Flora, compañera de Hipólita, aparece en el acto II, como buena amazona que es, empuñando arco y flechas; 
Trapantoja dispara al aire una pistola en el acto I; etc.); por otro lado, como ya mostraron Lafarga y Fernández Cabezón (2000 y 2003, respectivamente), las damas guerreras eran moneda corriente en las comedias heroicas y militares dieciochescas, tanto en forma de reinas y princesas (Petronila de Aragón en Las matronas catalanas (1783) de Moncín, Casandane en La más heroica espartana (1800) de Zavala y Zamora, Clorinda o la valerosa persiana (1781) de García Asensio, etc.) como de ejemplares ciudadanas y patriotas convertidas en líderes de su pueblo oprimido o acosado (María Pita es quizá el ejemplo más conocido en Defensa de La Coruña por la heroica María Pita (1784) de Valladares y Sotomayor, pero contamos también con La heroica Antona García (1755) de Cañizares, La española comandante fiel a su amor y a su patria (1787) de Fermín de Laviano, la Petronila de La defensa de Barcelona por la más fuerte amazona (1788) del mismo autor, la Margarita de Comella en El sitio de Calés (1790), varias más en El valor de las mugeres y triunfo de las murcianas de las lunas africanas (1779) de Cuadrado y Fernández de Arzuaga, y un largo etcétera que podemos consultar en Fernández Cabezón (2003: 118) y en Lafarga (2000: 33).

En muchos de estos casos, además, se reivindica la semejanza de estas heroínas con las míticas amazonas, a quienes remedan en determinación viril, arrojo y pericia en el manejo de las armas. Recordemos que la propia Gálvez había hecho ya algún pinito en el arte de poner en escena damas de este calibre, como ocurre con Zinda, la reina de Angola, en la tragedia que lleva su nombre ${ }^{28}$. Desde luego, en la comedia de la autora que aquí tratamos, la razón de ser de las amazonas Hipólita, Adelaida y Flora -al servicio de un tirano oriental, el rey de Siam- resulta bastante menos heroica que en la mayoría de las obras citadas, y no presenciamos a lo largo de los tres actos muestra alguna de su potencial bélico, pero lo cierto es que cumplen, como las otras damas guerreras nombradas más arriba, con la función de animar a la cazuela ofreciéndole un modelo femenino divertido y admirable, fuera de los estándares de la realidad social de su tiempo, y contribuyen con su absoluta falta de credibilidad a reforzar el espectáculo teatral que es la comedia popular de

28. Es interesante resaltar que al parecer la reina angoleña Zinga (Nzinga Mbandi, también conocida como Jinga, Ninga o Zingua), que inspira el drama trágico de Gálvez Zinda, trató de establecer una ginecocracia antes de convertirse al cristianismo a finales del XVII; sobre ella, fuente de inspiración literaria - Darío y De Sade, por ejemplo, se rindieron a su transgresora barbarie- circulan todo tipo de leyendas negras que contemplan la ninfomanía, los harenes masculinos y la organización de combates entre sus esclavos sexuales. En cualquier caso, y aunque nada de esto siquiera se insinua en la obra de Gálvez, queda claro que el tema del poder femenino le rondaba a la autora malagueña por las mientes.

Anales, 23, 2011, pp. 95-126 
entresiglos. Pero más allá de las concomitancias citadas, y de la presencia testimonial de soldados franceses y siameses como comparsas de los verdaderos protagonistas, o de las referencias a la existencia de un campamento francés en las inmediaciones del castillo de las amazonas, no hay en Las esclavas indicios de mayor parentesco con el teatro heroico de su tiempo, ni parafernalia militar, ni presencia de desfiles ni de otra batalla que no sea el enfrentamiento en el acto I entre el sargento Trapantoja y el eunuco Abufar, ni tampoco mensaje alguno en torno al honor colectivo o el amor a la patria.

Presenta, eso sí, cantidad y variedad de elementos, técnicas y recursos del teatro popular de su tiempo: la obra es un divertimento, un juego teatral con protagonistas de alta esfera (Carlos es embajador de Francia, y todos -Hipólita/Amalia, Adelaida/Elisa, Alberto y el propio Carlos- son hijos de los comandantes de los fuertes franceses en Asia) que sufren lances extraordinarios (secuestros por piratas, trata de blancas, coincidencias asombrosas, revelaciones familiares...), todo ello amenizado con el recurso de las mujeres «varoniles» y una puesta en escena deslumbrante, repleta de exotismo (un castillo en Siam, amazonas esclavas del rey, eunucos negros, tropas de soldados siameses, etc) y acompañada de música ${ }^{29}$.

Por otra parte, como ocurre a menudo en el teatro popular (Andioc, 1987:106), las heroínas de la comedia de Gálvez fueron en su infancia víctimas de una inesperada mutación de fortuna, que las condujo desde el centro - la familia europea, civilizada y católica - a la periferia -la soledad, la reclusión, la amenaza, Oriente bárbaro y salvaje-, pero la obra, que dramatiza ejemplarmente el tránsito ilustrado de las tinieblas hacia la luz, cierra satisfactoriamente ese periplo y lo culmina con la consabida agnición final, una carta del rey de Siam que explica el auténtico origen de Hipólita y Adelaida, gracias a la cual las jóvenes desorientadas recuperan simultáneamente identidad y posición social, e inician el camino de vuelta hacia la centralidad perdida. El

29. Sabemos sobradamente que la comedia popular gustaba de las protagonistas orientales y de la ambientación exótica, que le servía, además del propósito espectacular, para contrastar el punto de vista europeo -y reforzarlo, de paso- con usos y costumbres de territorios cuya extranjeridad «no civilizada» desafiaba la centralidad cultural del individuo dieciochesco. Sabemos también que la música es elemento fundamental en el teatro mayoritario de la época; en Las Esclavas Amazonas, las acotaciones donde se indica la música que ha de acompañar cada escena son una constante y van hasta la cancioncita popular -de sorprendente ritmo africano para ser ésta una comedia «asiática» - que canta Trapantoja disfrazado del esclavo negro Candonga en la escena $4^{a}$ del acto III. Ambos aspectos los estudia bien Angulo (2006: 181-185) a propósito del teatro de Comella: La buena esposa (1781), La esclava del Negro Ponto (1781) y La moscovita sensible (1794) son buenos ejemplos de mujeres orientales en el teatro popular de fines del XVIII. Para la música, ver las pp. 282-292 del mismo estudio. 
amor juega en todo este proceso un papel fundamental; se trata, como corresponde al género, de un amor en apuros, amor contrariado por la esquivez de la dama -que, como veremos es más que una mera convención teatral-, por lo descabellado de la situación (un joven embajador francés pretendiendo a una hermosa esclava oriental, amazona y propiedad del rey), y en última instancia por el escollo sobrevenido -malévolo intento del eunuco Emir para retener a sus amazonas- del inoportuno parentesco de los amantes. Pero la comedia popular, que todo lo puede, impone sus tozudas leyes dramáticas para resolver vía anagnórisis los duelos de amor, y para llegar al desenlace feliz -matrimonio doble, vuelta a casa de las jóvenes extraviadas y vuelta al redil de las mujeres varoniles- que su público aguarda.

Sabemos que gran parte de la dinámica amorosa de las comedias populares procede de -o se enraiza en- el teatro sentimental, como ya nos mostraron en su momento Pataky Kosove (1978), García Garrosa (1990) o Cañas Murillo (1994). Las historias desgraciadas de muchachas venidas a menos o asediadas en su honor, como la que nos ofrece Gálvez en esta comedia, eran moneda corriente en el drama sentimental español, que también solía servirse de la estratagema del reconocimiento final para resolver el embrollo y facilitar la unión de los amantes sin contravenir la ortodoxia social «aunque para ello tengan que hacer malabarismos dramáticos e ignorar los principios más elementales de la verosimilitud»(García Garrosa, 1990: 122). Pero además, los protagonistas de la obra de Gálvez, Carlos e Hipólita, están cortados con el mismo patrón del que se sirve la comedia sentimental para diseñar a sus héroes y heroínas ejemplares: Carlos es un héroe sentimental con todas las de la ley, compendio de virtudes, honorable, bondadoso y humano (como bien podemos observar cuando reprende al sargento Trapantoja por ordenar la muerte del eunuco Abufar en la escena $5^{\text {a }}$ del acto I), obstinado en el amor pero sensible a las razones y a los ruegos de Hipólita; encarna, en suma, todo lo que Emir (interesado, ambicioso, mentiroso y -sobre todo- misógino ${ }^{30}-$ ) no es. Ella no le va a la zaga: joven y bella, de origen desconocido, Hipólita oculta una sensibilidad y una vulnerabilidad extremas bajo su apariencia de indómita amazona, y cumple a la perfección el papel de heroína acosada en su virtud, al defenderse con ingenua franqueza y loable valor de las pretensiones del rey siamés de incorporarla a su serrallo, logrando así salvaguardar su honra e unirse a la guarda amazónica:

30. Adelaida- «¿A quién maldices, Emir?»

Emir- «A la raza entera de las mugeres, que altivas/la voz del honor desprecian» (Acto II, escena $2^{\mathrm{a}}$ ). 


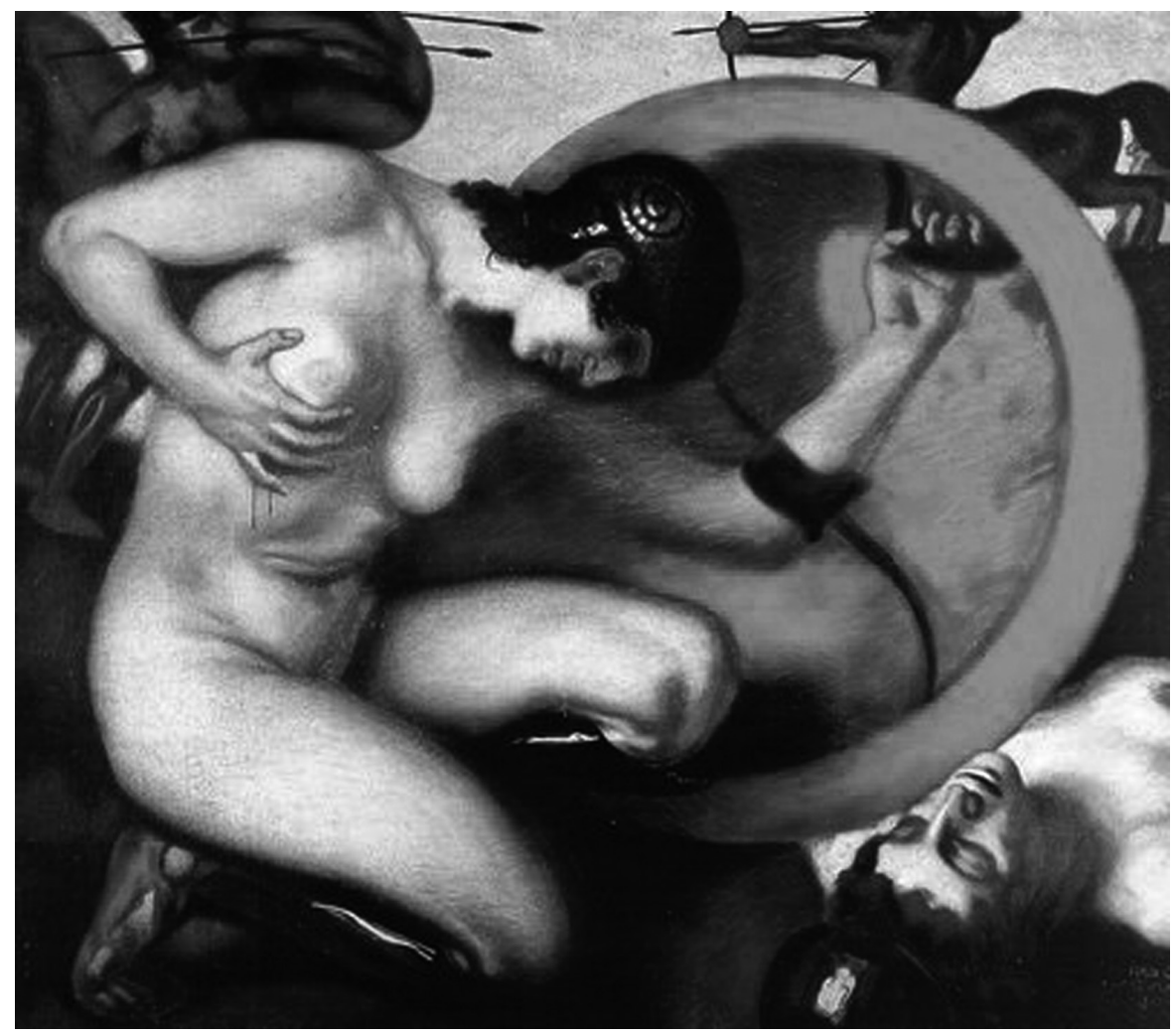

Amazona herida (Franz Von Stuck, 1904).

El [el Rey de Siam] prendado con extremo

de esa francesa gallarda

quiso entrase en el serrallo,

pero Hipólita tan vana

como sobervia, le dijo

que mientras la poligamia

no abandonase, podria

en él tenerla encerrada,

pero no lograr favores,

que pudieran infamarla,

porque en Siam pretendía

reinar sola o ser esclava.

En todo momento se ponen de manifiesto el honor y la virtud del uno y de la otra, fundamentalmente a través de monólogos en los que ambos dan rienda suelta a los sentimientos, eso sí, oportunamente tamizados por la contención, 
la razón y las conveniencias, como corresponde a su condición de héroes dieciochescos. Evidentemente, como ocurre en el teatro de corte sentimental, las huellas de la comedia áurea están presentes en el tratamiento que hace Gálvez del asunto amoroso: el enamoramiento a primera vista; la pasión irreprimible que parece -sólo parece- fuera del control de la voluntad de los amantes; la autonomía del yo -fundamentalmente de Hipólita-, inflexible en su postura frente a la coacción exterior; el conflicto entre la atracción mutua que experimentan los personajes -Hipólita y Carlos, Alberto y Adelaida- y los escollos circunstanciales que impiden que aquélla pueda convertirse en realidad; el doble plano en el que se mueven los personajes (la esfera de los amantes, con sus sentimientos elevados, su lenguaje cortesano y su inflexible código del honor, y por otro lado el ámbito de los criados, Trapantoja y Flora, donde predominan el ingenio, el sentido práctico y la sabiduría popular); el desparpajo del «gracioso» Trapantoja, quien «[...] fue ascendiendo/ por su caveza y sus puños/ desde tambor a sargento/ y á corrido todo el mundo/ con el mayor lucimiento» (Acto III, escena $1^{a}$ ), y su oportuno engaño para limar las asperezas entre los amantes, etc.; los citados anteriormente son sólo los más evidentes de los recursos de la obra de Gálvez que nos traen el regusto de nuestro mejor teatro cómico del Siglo de Oro.

Pero lo cierto es que por encima de todo ello se impone una visión del mundo absolutamente dieciochesca, que exalta la virtud y la sensibilidad, y que convierte la razón en un elemento moderador de las pasiones desenfrenadas. Y así, en virtud del respeto que todo héroe de su tiempo debe tributar al deber moral y al orden político-social, Carlos, que actúa como embajador de la civilización y de la concordia entre los pueblos, se aviene, a petición de Hipólita, a mantenerse alejado del castillo de las amazonas y se niega repetidamente a romper la palabra dada o a desestabilizar la armonía entre Francia y Siam por su incontinencia amorosa. Para resolver este dilema, ha de ser el sargento Trapantoja, bajo el disfraz del negro Candonga, quien se salte las convenciones y se introduzca en el castillo para ablandar la voluntad de Hipólita: «catáridas apliquemos/ a esta rebelde velleza/ de zelos, que la levanten/ ampolla y la hagan que ceda» (Acto II, escena $9^{a}$ ). Por su parte, Hipólita tiene poderosos motivos, que estudiaremos más adelante, para perseverar en su esquivez, de forma que su inclinación natural hacia el «sensible corazón» de Carlos (acto III, escena $6^{a}$ ), que nos revela en unos vehementes y apasionados monólogos donde debaten razón y sentimiento (véase, por ejemplo, la escena $6^{\text {a }}$ del acto III), se contiene públicamente hasta que las circunstancias se aclaran y se vislumbra una solución conveniente. Al final triunfa el amor, se restituye el orden familiar y social, se encaminan dos nuevos matrimonios y 
se reconstruye otro roto en el pasado (Trapantoja-Flora). En definitiva, nada que no encontremos en otras comedias de la propia autora y en la mayoría de las obras de trama sentimental y/o contenido didáctico de la misma época.

Lo cierto es que Las esclavas amazonas no tendría nada de particular si no hubiera sido escrita por una mujer, circunstancia poco frecuente en la comedia de entresiglos ${ }^{31}$, y si no actualizara - además, de una forma un tanto peculiar- un tema, el de las amazonas, que no había sido nunca hasta entonces llevado a las tablas españolas por una dramaturga. Parece bastante obvio, además, que entre ambos hechos -el que se trate de una escritora y que ésta elija precisamente el tema de las amazonas para su comedia- existe una relación más que casual, que hay que entender, a mi juicio, poniéndolo en relación con el resto de la producción dramática de Gálvez. No creo en absoluto que Las esclavas amazonas constituya un aparte en la dramaturgia de la autora, por mucho que ésta se incline hacia los esquemas populares y ponga en escena recursos nuevos en su trayectoria teatral. Aún más, me atrevería a decir que esta comedia -la última original de su autora- supone el punto final de un ciclo dramático con un tema único, planteado desde diferentes ópticas y llevado a escena a través de géneros varios, pero recurrente, insistente, obsesivo: la posición de las mujeres, de lo femenino, dentro del universo patriarcal dieciochesco.

La presentación, nada al uso, que nos hace Gálvez de sus amazonas tiene no poco que ver con la interpretación de lo femenino que desea transmitrnos la obra. Hipólita, Adelaida y Flora son, de hecho, unas amazonas insólitas en la historia de nuestro teatro, no tanto por su inusual ubicación siamesa (al fin y al cabo, la geografía "amazónica» se extiende de un extremo a otro del globo, incluyendo África, América, Asia Menor, India e incluso Oceanía: C. Alonso del Real, 1967:186-202) como por el hecho de que ninguna de las guerreras protagonistas de esta comedia lo sea por decisión propia, vocación o nacimiento, sino a resultas de la negativa de Hipólita a ingresar en el harén real. Nos cuenta Gálvez que «el rey celebró la extravagancia» (acto I, escena $1^{a}$ ) eximiéndola a ella y sus acompañantes de la esclavitud sexual pretendida, pero condenándolas a «arrastrar las cadenas que el despotismo ha forjado»

31. Los nombres de escritoras de comedia recogidas por los catálogos (Serrano y Sanz, 1975; Herrera Navarro, 1993; Hormigón, 1996-97) y los estudios sobre autoras del XVIII (Bordiga Grinstein, 2002; Palacios Fernández, 2002; Zorrozua, 1997) apenas sobrepasan la media docena. Ninguna de ellas, desde luego, presenta una diversidad en su trayectoria dramática ni por asomo similar a la de Gálvez, y pocas se atreven a ir más allá de la comedia didáctica o de costumbres. Tenemos un excelente estudio de una obra de las más osadas en este sentido, La dama misterio, capitán marino de María de Laborda, en este mismo volumen (Ver Angulo Egea). 
(acto II, escena $12^{a}$ ) mediante el celibato, la reclusión y los únicos ejercicios de la caza y de las armas. Tanto Adelaida como Flora están prestas a renunciar a su condición de amazonas y se confiesan ansiosas de encontrar una vía de escape a ese involuntario ostracismo, dispuestas a marcharse con los franceses a cualquier precio: «voy a ver a los franceses/» -dice Adelaida a Emir- «porque yo no tengo nada/ de amazona [...] al contrario/ lo que tengo es mucha gana/de ver si esos europeos/ tienen tan negras las caras/ como tú [...]» (acto I, escena $2^{a}$ ); Hipólita, sin embargo, que no en vano lleva el nombre de una mítica reina amazona ${ }^{32}$, se declara contenta con su destino, a salvo -entre los muros del castillo donde sólo habitan mujeres y eunucos- de las insidias de los hombres, del engaño amoroso, de la eterna perfidia masculina. Se confiesa enemiga acérrima del otro sexo y hace ondear, como seña de identidad, la bandera de la arrogancia, la altivez:

$$
\begin{aligned}
& {[\ldots .] \text { soy tan bana/tan sobervia y altiva }} \\
& \text { que no pienso que se halla } \\
& \text { hombre alguno en este glovo } \\
& \text { que merezca una mirada } \\
& \text { de Hipólita [...] (Acto I, escena } 2^{a} \text { ). }
\end{aligned}
$$

Pero mientras públicamente hace gala de autonomía, en lo privado bebe los vientos por el embajador francés, y al final -como su predecesora griegaacepta de buen grado la oferta amorosa de Carlos olvidándose de sus propósitos de esquivez y de su condición de amazona real. En realidad, fuera de una supuesta habilidad con las armas y de una forzada abstinencia sexual, poco o nada queda en las de Gálvez de las míticas guerreras que nos legó la tradición. Su aparente «independencia» es en realidad soledad, y su «amazonía» resulta ser una impostura, un disfraz, bajo el cual... ¿qué se oculta?

Se esconde, como bien confiesa la propia Hipólita, el miedo a ser traicionada, a sufrir por amor, a exponerse más de lo necesario. La trayectoria de Hipólita, al fin y al cabo, bien justifica este temor: secuestrada por unos piratas,

32. Hipólita, poseedora del cinturón de su padre Ares, símbolo de fuerza y poder, pero también de castidad y virginidad (Chevalier y Gheerbrant, 1969: 185-6). Según la tradición literaria (la versión más antigua es la de Eurípides en Héracles (417 a. de C.), éste fue enviado a recuperar el cinturón de Hipólita, lo cual implicaba de paso poseer a su propietaria. La variante más curiosa de este noveno trabajo de Heracles, recogida por Apolodoro (Graves, 1967, 2: 123), cuenta que seducida Hipólita por la belleza física y la musculatura de Heracles, consiente en darle su cinturón -y algo más, sin duda-. Finalmente, la intervención de Hera, celosa de Hipólita, lleva a la muerte de ésta a manos de Heracles, que huye con el cinturón. La imagen de Hipólita que ofrece esta variante del mito no es, desde luego, la de una virgen intocable y desdeñosa, sino la de una mujer sensible al encanto viril.

Anales, 23, 2011, pp. 95-126 
vendida a Emir, ofrecida como presente sexual al rey de Siam, recluida en un castillo y condenada al celibato. No es de extrañar que su única expectativa respecto al sexo contrario sea la de ser engañada, ni que disfrace de desdén y altivez la necesidad de autoprotegerse. Nos lo explica con buenas razones en la escena $3^{\mathrm{a}}$ del acto III:

He aquí por qué yo á los hombres

tan altanera aborrezco;

suspiran, ruegan, ponderan

los sentimientos más tiernos

del amor; y si consiguen

que se les oiga a lo menos

ya se olvidan de la queja,

y dejan obrar al tiempo (Acto III, escena $3^{\text {a }}$ )

Y nos lo repite con más convencimiento aún después de creerse engañada por Carlos:

Ves, Adelaida, el perverso

seductor? todos los hombres son lo mismo: vive en ellos

la mentira, la falacia,

la impostura, el fingimiento

y en Carlos ¡Ay! más que todos (Acto III, escena $4^{a}$ )

Desde su condición de amazona -y por tanto, de virgen- impuesta por un hombre y aceptada por ella de buen grado, el tesón con que defiende su virtud tiene mucho que ver con el deseo de blindar un territorio personal donde no pueda ser objeto de humillación ni de transacción económica; su reticencia al matrimonio, que entiende como pérdida de este espacio propio, y la insistencia con la que defiende que soledad y celibato constituyen el único espacio de libertad de una mujer frente a «las cadenas del amor» (acto III, escena $\left.6^{a}\right)$, también; no deja de tener su gracia, por cierto, la modernidad que yace en el profundo horror con el que Hipólita se refiere en la obra al lazo conyugal: " $i$ Yo sujeta para siempre/con el lazo de himeneo/a los caprichos de un hombre! de pensarlo me estremezco» (Acto III, escena $4^{a}$ ), aunque al final quede encantada con el amor de Carlos. Aunque el título de la obra suene oximorónico e incluso ridículo, esconde una interesante paradoja con la que Gálvez parece resumir una de las escasas opciones vitales con las que cuentan las mujeres: ser esclavas y a la vez amazonas, no tener libertad pero ser libres, guardar un reducto íntimo, inviolable, de autonomía: el derecho a no amar, a no entregarse en cuerpo y alma: «que reyno, aunque Esclava soy/ porque en la clase en que estoy/ nadie puede dominarme» (Acto II, escena $12^{a}$ ); «[ ... yo, esclava aquí, soy libre; /y mas este estado aprecio/ que la corona del mundo» (Acto III, escena $5^{a}$ ). 
La esquivez de las amazonas de Gálvez esconde mucho más que un recurso moretiano para que al final de la obra venza el amor y la autora conquiste el plácet del público (aunque es seguro que este último propósito se mantuvo como referencia en la miente de la autora mientras pergeñaba su comedia). La prueba es que Hipólita encaja a la perfección entre el resto de heroínas de Gálvez, especialmente entre las de sus tragedias, víctimas de diferentes variantes de la opresión patriarcal en un mundo misógino y hostil (Establier, 2005).

Las esclavas amazonas no es sino un paso más en la lucha que emprende la autora malagueña desde las tablas contra la esclavitud en general y la que sufren las mujeres en particular ${ }^{33}$, e Hipólita es otra víctima, otro objeto más de la violencia masculina: «En vano en este recinto /prodiga la primavera/ sus flores: despreciable/a pesar de la belleza de sus dones será siempre/ la mansión de donde reyna/la opresión, la esclavitud [...]» (Acto II, escena $3^{a}$ ). Claro está que la amazona desdeñosa no se suicida al final de la obra, como sí lo hacen otras heroínas de Gálvez (Safo, Blanca de Rossi o Florinda). Hipólita se enamora por «la primera vez»(acto III, escena $6^{\mathrm{a}}$ ), y el amor de Carlos, un amor civilizado, sensible, respetuoso, de igual a igual, es en este caso una liberación y una fiesta: «amante y rendido/ llevarla a Europa pudiera/ donde premiando mi afecto, libre dichosa y contenta/ viviese entre mil delicias»; (acto II, escena $5^{\mathrm{a}}$ ). Descartada la solución trágica del suicidio, de entre los dos únicos senderos de vida que se le ofrecen a Hipólita -continuar como esclava virgen del tirano oriental o ceder su cinturón como la amazona griega que le da nombre ${ }^{34}$ (en nuestro caso volver a Europa de la mano del héroe enamorado para formar una familia), su elección -la segunda, claro- es razonable, profundamente dieciochesca y apropiada para la comedia.

Huelga decir que estamos ante una obra de entretenimiento y que un final catártico como los señalados para otras obras no encajaría en el patrón. Pese a todo, merece la pena preguntarse por qué cierra Gálvez el ciclo de su producción dramática original rescatando a Hipólita de su pasado de tienieblas y ofreciéndole un futuro europeo y feliz. Y es que, desde la óptica de una autora del siglo XVIII, que jamás se ensaña en sus obras contra el amor -sí, no obstante, contra las prácticas del mal amor-, el enamoramiento de Hipólita nunca puede ser una cesión o claudicación, antes bien, es un regalo («mis deseos/premia el amor» (acto III, escena 9a), un desiderátum, una utopía que contempla la posibilidad de un destino diferente -diferente al de Florinda, al de Blanca de Rossi, al de Safo y al de la Hipólita mítica- para las mujeres. La

33. No es la primera vez por cierto que Gálvez funde alegato antiesclavista y feminista en un solo discurso, como bien se ve en Zinda (Establier, 2005: 150-152).

34. Ver nota 32.

Anales, 23, 2011, pp. 95-126 
esquivez no es ridiculizada ni censurada en la obra de Gálvez, como sí lo fue en las de otros dramaturgos que la precedieron en el tratamiento del tema; más bien es reconducida hacia un lugar donde la mujer no necesariamente ha de claudicar o entregarse, un lugar en el cual es posible encontrar un compañero digno; un lugar donde no es necesario renunciar al amor para no sufrir, donde no hay que ser ni esclava ni amazona para conservar la dignidad femenina, donde entregar el mítico cinturón no implica la muerte ni la humillación. Gálvez subvierte el mito, sin llegar a la transgresión desafiante de Anne-Marie du Boccage (Las amazonas) o de Heinrich Von Kleist (Pentesilea) ${ }^{35}$, para ofrecer una salida feliz al destino femenino.

La obra es, en suma, entretenida en su forma (el tira y afloja entre Carlos e Hipólita resulta un tanto cansino, pero los enredos de Trapantoja ayudan sin duda a aligerar la carga sentimental)-, descabellada argumentalmente y bastante menos superficial en su fondo de lo que a primera vista pudiera parecer. Coincido con mucho de lo dicho hasta el momento sobre esta comedia de Gálvez, especialmente con la visión que ofrece E. F. Lewis de la eslava amazona como símbolo de la mujer dieciochesca y como trasunto de la propia autora (2004:111) aunque discrepo del enfoque excesivamente actual con el que se la interpreta y/o valora en ocasiones. La denuncia que subyace en ella acerca de la posición de lo femenino es bastante menos «conservadora» (Flepp, 2006: 70-1) de lo que a primera vista pueda parecer, y la solución final - la aparente claudicación de la amazona, rescatada por el héroe de su destino adverso, y su aceptación del estatus matrimonial- no se adecua, claro está, a las metas del feminismo contemporáneo, pero encaja sin estridencias en la línea de las comedias de la autora y en la ideología sexual de una dramaturga de su tiempo: la amazona-esclava 'por fuerza' elige al final su destino, que conduce hacia la felicidad, la civilización, la identidad, el amor, la familia, el equilibrio personal, el orden social y la armonía sexual. Como término de una galería de heroínas de Gálvez violadas, autoinmoladas o asesinadas, esta relectura del

35. Con su tragedia Las amazonas (1748), Madame du Boccage inaugura un ciclo de inversión del mito amazónico muy productivo en las reinterpretaciones del siglo XX. Frente a las versiones «oficiales» del mito, según las cuales Teseo fue vencedor de las amazonas y seductor -y a veces violador- de Antíope, en la obra de Boccage el héroe es prisionero de las guerreras, admirador de su superioridad y ardiente enamorado de Antíope. No en vano se atribuyó el epíteto de «amazona» a su autora. Por su parte, sesenta años más tarde Kleist invierte en Pentesilea (1808) el enfrentamiento entre Aquiles y Pentesilea, y convierte a ésta en artífice del asesinato del que es víctima según la tradición legendaria. Al llegar el siglo XX, estas inversiones que transforman a las amazonas en vencedoras -temporales, por lo general-del héroe se multiplican, no sólo desde la literatura feminista, sino también desde el cine o el cómic. Remito para esto al trabajo que coordina Leduc (2008). 
mito amazónico -el venturoso porvenir que se le ofrece a Hipólita, Adelaida y Flora- es a la vez una reconciliación de la autora con las expectativas para su propio género y un compromiso entre sus intereses dramáticos y la comedia popular de entresiglos.

\section{BIBLIOGRAFÍA}

AnDioc, René, Teatro y sociedad en el Madrid del del siglo XVIII, Madrid, Castalia, 1987.

- «Introducción» a M ${ }^{a}$ Rosa de Gálvez, La familia a la moda, Grupo de Estudios del siglo XVIII, Universidad de Salamanca, 2001, pp. 9-101.

Andioc, René y Coulon, Mireille, Cartelera teatral madrileña del siglo XVIII (1708-1808), Toulouse, Presses Universitaires du Mirail, 1996, 2 vols.

ANGULO EGEA, María, «Fingir y aparentar. La imagen de las mujeres en el teatro sentimental de Luciano Francisco Comella (1751-1812)», Dieciocho, 25.2 (2002), pp. 281-301.

- Luciano Francisco Comella (1751-1812). Otra cara del teatro de la Ilustración, Alicante, Servicio de publicaciones de la Universidad de Alicante, 2006.

BACHOFEN, J. J. El matriarcado: una investigación sobre la ginecocracia en el mundo antiguo según su naturaleza religiosa y jurídica, Torrejón de Ardoz, Madrid, Akal, 1987.

BLOCK, Josine H. The Early Amazons: Modern and Ancient Perspectives on a Persistent Myth, Leiden, Brill, 1995.

Bordiga Grinstein, Julia, La rosa trágica de Málaga: vida y obra de María Rosa de Gálvez, Anejos de Dieciocho, 3, The University of Virginia, 2003.

- «Panorama de la dramaturgia femenina española en la segunda mitad del siglo XVIII y principios del siglo XIX», Dieciocho, 25.2 (2002), pp. 195-218.

BorgeAud, Philippe (dir), La Mythologie du matriarcat. L'Atélier de Johan Jakob Bachofen, Genève, Droz, 1999.

CAlDERA, Ermanno, Il teatro di Moreto, Pisa, Librería Goliardica, 1960.

CAÑAS Murillo, Jesús, La comedia sentimental, género español del siglo XVIII, Cáceres, Universidad de Extremadura, 1994.

CARRERAS LÓPEZ, Juan José, «Entre la zarzuela y la ópera de corte: representaciones cortesanas en el Buen Retiro entre 1720 y 1724»,en Kleinertz, Rainer (ed.), Teatro y música en España, (siglo XVIII), Kassel-Berlín, Reichenberger, 1996, pp. 49-77.

CAstañeda, James, Agustín Moreto, Twayne Publishers, 1974.

CASTillo, Juan del, Las amazonas de España y prodigio de Castilla, 1701, [s.l.], [s.n.].

CHECA, José, «Los clásicos en la preceptiva dramática del siglo XVIII», Cuadernos de Teatro Clásico, 5 (1990), pp. 13-31. 
Chevalier, Alain, y Gheerbrant, Jean, Dictionnaire des symboles, Paris, Robert Laffont, 1969, pp. 185-186.

CoE, Ada M., Catálogo bibliográfico y crítico de las comedias anunciadas en los periódicos de Madrid desde 1661 hasta 1819, Maryland, John Hopkins Press, 1935.

Coulon, Mireille, «Ramón de la Cruz et le mythe des amazones», Bulletin Hispanique, 91 (1989), nº 1, pp. 5-19.

Cruz, Ramón de la, La República de las mujeres, en E. Cotarelo (ed.), Sainetes de Don Ramón de la Cruz, en su mayoría inéditos, tomo II, Nueva Biblioteca de Autores Españoles, nº 23, Madrid, Bailly-Baillière, 1915.

DAVIS, Charles, «Análisis por base de datos de los libros de cuentas de los corrales de Madrid:1708-1719», en García Lorenzo, L. y J.E. Varey (eds.), Teatros y vida teatral en el Siglo de Oro a través de las fuentes documentales, London, Tamesis Books, 1991, pp. 191-204.

Delgado, $\mathrm{M}^{\mathrm{a}}$ José (ed.), Las comedias de Ana Caro. «Valor, agravio y mujer» y «El conde Partinuplés», Nueva York, Peter Lang, 1998.

Establier PÉREZ, Helena, «Una dramaturgia feminista para el siglo XVIII: Las obras de María Rosa Gálvez de Cabrera en la comedia de costumbres ilustrada», Dieciocho, 29. 2 (Fall), 2006, pp. 179-203.

- «El teatro trágico de María Rosa Gálvez de Cabrera en el tránsito de la Ilustración al Romanticismo: una utopía femenina y feminista», Anales de Literatura Española, 18 (2005), pp. 143-161.

- «Florinda perdió su flor. La leyenda de La Cava, el teatro neoclásico español y la tragedia de María Rosa Gálvez de Cabrera», Boletín de la Biblioteca de Menéndez Pelayo, LXXXV (2009), pp. 195-219.

FERNÁNDEZ CABEZÓN, Rosalía, «La mujer guerrera en el teatro español de fines del siglo XVIII», Anuario de Estudios Filológicos, XXVI (2003), pp. 117-136.

FLEPP, Catherine, «Les fictions du féminin dans l'oeuvre de María Rosa de Gálvez (1768-1806)», en Françoise Étienvre (dir.), Regards sur les Espagnoles créatrices, Paris, Presses Sorbonne Nouvelle, 2006, pp. 61-73.

GÁlvez, María Rosa de, Las Esclavas Amazonas, Biblioteca Nacional, ms. 16507.

- Obras Poéticas, Madrid, Imprenta Real, 1804.

GARCíA GARROSA, María Jesús, La retórica de las lágrimas. La comedia sentimental española 1751-1802, Universidad de Valladolid, 1990.

Graves, Robert, Les Mythes grecs, Paris, Hachette Littératures, 1967, 2 vols.

GuYON, Claude-Marie, Histoire des Amazones anciennes et modernes, Paris, Villette, 1740 .

HeRnÁndez ReYes, Dalia, «La recepción del teatro de Agustín Moreto en la Ciudad de México del siglo XVIII», Bulletin of Spanish Studies, LXXXV, 7-8 (2008), pp. 195-223. 
Herrera NaVARro, Jerónimo, Catálogo de autores teatrales del siglo XVIII, Madrid, Madrid, Fundación Universitaria Española, 1993.

Hormigón, Juan Antonio (ed.), Autoras en la historia del teatro español (15001994), Madrid, PADEE, 1996-7, 2 vols.

Índice general alfabético de todos los títulos de comedias que se han escrito por varios autores, antiguos, y modernos y de los Autos Sacramentales y alegóricos, assi de D. Pedro Calderón de la Barca, como de otros autores clásicos. Madrid, en la Imprenta de Alfonso de Mora, 1735. Alicante, Biblioteca Virtual Miguel de Cervantes, 2008.

LAFARGA, Francisco. «La mujer y la guerra en el teatro español del siglo XVIII: La defensa de Barcelona por la más fuerte amazona de F. del Rey», en Femmes et guerre en Mediterránée (XVIIIème-XIXème siècles), Pub. des Universités de Barcelone et Montpellier, 2000, pp. 43-51.

LEDUC, Guyonne (dir.), Réalité et représentation des amazones, Paris, L'Harmattan, 2008.

Literatura de cordel y teatro en España, 1675-1825. http://www.pliegos.culturaspopulares.org/comedias.php

LEWIS, Elizabeth Franklin, Women Writers in the Spanish Enlightenment. The Pursuit of Happiness, Hampshire/Burlington, Ashgate, 2004.

López Alemany, Ignacio, y J.E. VArey, El teatro palaciego en Madrid, 1707-1724, Cambridge University Press, 2006.

MaCKenZIE, Ann L. Francisco de Rojas Zorrilla y Agustín Moreto: análisis, Liverpool University Press, 1994.

MCKENDRICK, Melveena, Woman and Society in the Spanish Drama of the Golden Age. A Study of the «Mujer Varonil.» Cambridge, Cambridge University Press, 1974.

Moreto, Agustín, El desdén, con el desdén, Ed. de Francisco Rico, Madrid, Castalia, 1971.

- El desdén, con el desdén, Ed. de Enrico di Pastena y estudio preliminar de John E. Varey, Barcelona, Crítica, 1999.

PALACIOS FERNÁNDEZ, Emilio, «El teatro barroco en una carta de Benardo de Iriarte al conde de Aranda (1767)», Cuadernos de Teatro Clásico, 5 (1990), pp. 43-64.

— «Teatro», en F. Aguilar Piñal (ed.), Historia literaria de España en el siglo XVIII, Madrid, Trotta-CSIC, 1996, pp. 135-233.

- La mujer y las letras en la España del siglo XVIII, Madrid, Ediciones Laberinto, 2002.

PASTRE, Geneviève, Les Amazones. Du mythe à l'histoire, Paris, G. Pastre/les octaviennes, 1996.

PATAKy Kosove, Joan Lynne. The "Comedia Lacrimosa» and Spanish Romantic Drama (173-1865). London, Tamesis, 1978. 
REAL, Carlos Alonso del, Realidad y leyenda de las amazonas, Madrid, EspasaCalpe, 1967.

Romanos, Melchora, «Aspectos de la comicidad en la Trilogía de los Pizarros de Tirso de Molina», en Arellano, I., Oteiza, B. y Zugasti, M. (eds.), El ingenio cómico de Tirso de Molina: Actas del Congreso Internacional, Pamplona, Universidad de Navarra, 27-29 de abril de 1998, Madrid, Pamplona, Instituto de Estudios Tirsianos, 1998, pp. 281-292.

SAmuel, Pierre. Amazones, guerrières et gaillardes, Grenoble, P.U. de Grenoble, 1975.

SAURA SÁNCHEZ, Alfonso, « Teatro y teatro francés traducido en el Madrid de 1808: una aproximación», Anales de Filología Francesa, 16 (2008), pp. 205-221.

SERrano y SAnZ, Manuel, Apuntes para una Biblioteca de Escritoras Españolas desde 1401 a 1833, 2 vols., Madrid, Atlas, 1975.

Solís, Antonio de, Las Amazonas de Escitia, Valencia. Imprenta de la Viuda de José de Orga, 1764.

TiRso De Molina, Las amazonas en las Indias, en M. Zugasti (ed.) Trilogía de los Pizarros, vol. III, Kassel, Fundación Obra Pía de los Pizarros-Reichenberger, 1993.

Títulos de todas las comedias que en verso español y portugués se han impresso hasta el año 1716. En Jaime Moll, "Comedias sueltas no identificadas», Alicante, Biblioteca Virtual Miguel de Cervantes, 2009.

Tyrrell, William Blake, Las amazonas. Un estudio de los mitos atenienses, México, Fondo de Cultura Económica, 1989.

VAREY, J.E. y Charles DAVIS, Los libros de cuentas en los corrales de comedias de Madrid: 1706-1719. Estudio y documentos, London, Tamesis, 1992.

Vega CARPIO, Lope Félix de, Las mujeres sin hombres, en Comedias pastoriles y Comedias mitológicas, Biblioteca de Autores Españoles, tomo CLXXXVIII, Madrid, Atlas, 1965, pp. 375-426.

- Las grandezas de Alejandro, en Comedias mitológicas y Comedias históricas de asunto extranjero, Biblioteca de Autores Españoles, tomo CXC, Madrid, Atlas, 1966, pp. 331-390.

- Las justas de Tebas y reina de las amazonas, en Obras Completas, Comedias, I, Madrid, Turner, 1993, pp. 737-813.

ZorrozuA, Ma del Pilar, Escritoras de la Ilustración española (1759-1808), Tesis Doctoral, Universidad de Deusto, 1997.

Fecha de recepción: 03/04/2010

Fecha de aceptación: 07/05/2010 